\title{
Kinetics and Mechanistic Study of Oxidation of Pyridine Derivative by Cerium(IV) in Aqueous Perchloric Acid
}

\author{
Ahmed Fawzy ${ }^{1,2, ~ *, ~ I s h a q ~ A . ~ Z a a f a r a n y ~}{ }^{1}$, Fahd A. Tirkistani ${ }^{1}$, Ameena Al-Bonayan ${ }^{1}$, \\ Faten A. Aljiffrey ${ }^{1}$ \\ ${ }^{1}$ Chemistry Department, Faculty of Applied Science, Umm Al-Qura University, Makkah, Saudi Arabia \\ ${ }^{2}$ Chemistry Department, Faculty of Science, Assiut University, Assiut, Egypt
}

\section{Email address:}

afsaad13@yahoo.com (A. Fawzy), iazaafarany@uqu.edu.sa (I. A. Zaafarany),drfahd999@gmail.com (F. A. Tirkistani), benayana@hotmail.com (A. Al-Bonayan), fateng25@hotmail.com (F. A. Aljiffrey)

\section{To cite this article:}

Ahmed Fawzy, Ishaq A. Zaafarany, Fahd A. Tirkistani, Ameena Al-Bonayan, Faten A. Aljiffrey. Kinetics and Mechanistic Study of Oxidation of Pyridine Derivative by Cerium(IV) in Aqueous Perchloric Acid. American Journal of Physical Chemistry. Vol. 5, No. 1, 2016, pp. 10-16. doi: $10.11648 /$ j.ajpc.20160501.12

\begin{abstract}
The kinetics of oxidation of $N, N$-dimethyl- $N$ '-(pyridin-2-yl) formamidine (Py-F) by cerium(IV) was studied spectrophotometrically in aqueous perchloric acid solutions at a constant ionic strength of $1.0 \mathrm{~mol} \mathrm{dm}^{-3}$ and at $20^{\circ} \mathrm{C}$. The reaction showed first order dependence with respect to [Ce(IV)] and less than unit order with respect to [Py-F]. The reaction exhibited negative fractional-first order kinetics with respect to $\left[\mathrm{H}^{+}\right]$. The rate of reaction was not significantly affected by variation of either ionic strength or dielectric constant of the reaction medium. Addition of cerium(III) product did not affect the reaction rate. A suitable mechanistic scheme for the oxidation reaction has been proposed. The final oxidation products were identified as 2-aminopyridine, dimethylamine and carbon dioxide. The activation parameters have been evaluated and discussed. The rate law associated with the reaction mechanism was derived.
\end{abstract}

Keywords: Kinetics, Mechanism, Oxidation, Pyridine Derivative, Cerium(IV)

\section{Introduction}

Aminopyridine is an important organic compound which is used in the production of the drugs piroxicam, sulfa pyridine, tenoxicam, and tripelennamine. Also, substituted formamidines have achieved considerable significance during the last few decades [1-4] due to their very broad spectrum of biological activity. The biochemical potentialities of formamidines include monoamine oxidase inhibitors $[1,2]$, adrenergic and neurochemical receptors [3, 4]. The $N, N$-dialkyl derivatives are highly effective acaricides and the most rewarding of these studies resulted in the discovery of acaricide insecticide chlordimeform. The oxidative cleavage of formamidines is quite important, since the $N, N$-dialkyl formamidine group is one of the most versatile protecting groups, especially in biosynthetic applications.

Cerium(IV) is a powerful one electron oxidizing agent in acid media [5-20]. Oxidation by cerium(IV) in sulfuric acid solutions have conclusively been established [5-13]. Nevertheless, little reports on cerium(IV) oxidation in perchloric acid solutions [14-19], probably due to presence of dimers and polymers of cerium(IV) in such solutions [19]. However, the reactions of cerium(IV) in perchloric acid medium proceed much faster than those in sulfuric acid medium. Cerium(IV) oxidations of various substrates are found to follow different mechanisms, depending upon the acid medium used. Such oxidation are generally interesting to understand the different pathways of the reactions and different active forms of cerium(IV).

No work has been reported about the kinetics and mechanism of oxidation of pyridine derivatives by cerium(IV). This observation prompted us to investigate the title reaction. We aim to establish the optimum conditions affecting oxidation of $N, N$-dimethyl- $N$ '-(pyridin-2-yl) formamidine (Py-F) by cerium(IV) in perchloric acid solutions, to understand the kinetically active species of $\mathrm{Ce}(\mathrm{IV})$ and finally to elucidate a plausible oxidation mechanism.

\section{Experimental}

\subsection{Materials}

All chemicals employed in the present work were of 
reagent grade and their solutions were prepared by dissolving the requisite amounts of the samples in doubly distilled water The stock solution of $\mathrm{Py}-\mathrm{F}$ was prepared as reported elsewhere [21]. Cerium(IV) solution was freshly prepared by dissolving ceric ammonium sulfate in a $1.0 \mathrm{~mol} \mathrm{dm}{ }^{-3}$ sulfuric acid, diluted with double distilled water and kept for overnight. Concentration of cerium(IV) was ascertained by titrating against standard ferrous ammonium sulfate solution using ferroin as an internal indicator. The solution of cerium(IV) was stored in a dark glass bottle and was used after $24 \mathrm{~h}$, since the hydrolysis is negligible small or ruled out after $12 \mathrm{~h}$ of preparation [22]. Cerium(III) solution was prepared by dissolving cerium(III) acetate in water.

\subsection{Kinetic Measurements}

Kinetic measurements were followed under pseudo-first order conditions where Py-F was present in a large excess over that of cerium(IV). The progress of the reaction was followed by monitoring the decrease in absorbance of cerium(IV) as a function of time at $\lambda=316 \mathrm{~nm}$, its absorption maximum, whereas the other constituents of the reaction mixture do not absorb significantly at this wavelength. The applicability of Beer's law for cerium(IV)at $315 \mathrm{~nm}$ has been verified giving $\varepsilon=4371 \pm 28 \mathrm{dm}^{3} \mathrm{~mol}^{-1} \mathrm{~cm}^{-1}$ in agreement with the earlier reports $[15,16]$. The absorbance measurements were made in a thermostatted quartz cell of a pathlength $1.0 \mathrm{~cm}$ on a Shimadzu UV-VIS-NIR-3600 doublebeam spectrophotometer. First order plots of $\ln$ (absorbance) versus time were found to be good straight lines and the observed first order rate constant values $\left(k_{\mathrm{obs}}\right)$ were calculated as the gradients of such plots. The rate constants were reproducible to within $4 \%$ and were the average of at least two independent kinetic runs. The effect of dissolved oxygen on the reaction rate was checked by monitoring the reaction in a nitrogen atmosphere. No significant difference between the results obtained under nitrogen and in the presence of air was observed.

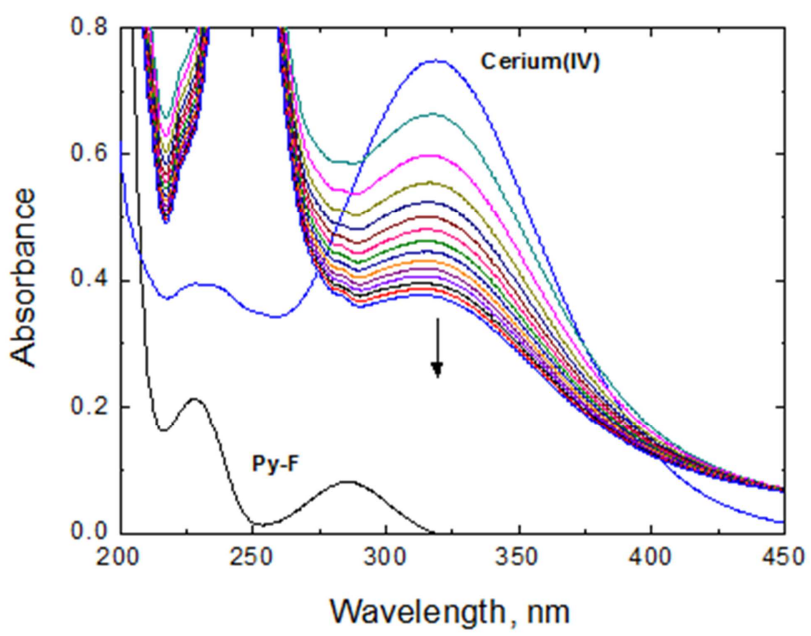

Figure 1. Time-resolved spectra during oxidation of Py-F by $\mathrm{Ce}(\mathrm{IV})$ in perchloric acid solution. $[\mathrm{Py}-\mathrm{F}]=8.0 \times 10^{-3},[\mathrm{Ce}(\mathrm{IV})]=2.0 \times 10^{-4},\left[\mathrm{H}^{+}\right]=$ 0.3 and $I=1.0 \mathrm{~mol} \mathrm{dm}^{-3}$ at $25^{\circ} \mathrm{C}$. Scanning time intervals $=8 \mathrm{~min}$.
Time-resolved spectra during the oxidation of Py-F by $\mathrm{Ce}(\mathrm{IV})$ in aqueous perchloric acid solutions are shown in Figure 1. The scanned spectra indicate gradual disappearance of $\mathrm{Ce}(\mathrm{IV})$ band at its absorption maximum with time as a result of its reduction to $\mathrm{Ce}(\mathrm{III})$.

\section{Results}

\subsection{Stoichiometry and Product Analysis}

Reaction mixtures containing various amounts of Ce(IV) and Py-F at constant $\left[\mathrm{H}^{+}\right]$, ionic strength and temperature were allowed to react for $24 \mathrm{~h}$ in closed vessels for completion of reactions. The unreacted [Ce(IV)] was assayed spectrophotometrically at $315 \mathrm{~nm}$ as well as by titrating against standard ferrous ammonium sulfate solution. The results indicated that two moles of $\mathrm{Ce}(\mathrm{IV})$ were consumed by one mole of Py-F yielding the oxidation products as shown in the following equation,

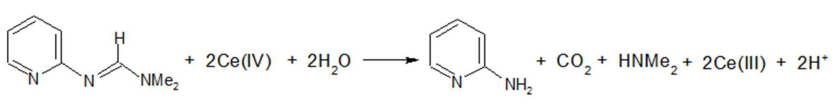

(I)

(II)

(III)

where the compounds (I), (II) and (III) are $N, N$-dimethyl- $N$ '(pyridin-2-yl) formamidine (Py-F), 2-aminopyridine and dimethylamine, respectively. The above stoichiometric equation is consistent with the results of product analysis as described elsewhere [21]. 2-Aminopyridine and dimethylamine were identified by liquid chromatography and spot tests [24], respectively, and $\mathrm{CO}_{2}$ by lime water.

\subsection{Reaction Order with Respect to the Reactants}

The reaction orders $(n)$ with respect to the different reactants were determined from the slopes of $\log k_{\mathrm{obs}}$ versus $\log$ (concentration) plots by varying the concentrations $(\mathrm{C})$ of substrate and acid, in turn, while keeping other conditions constant.

The oxidant, cerium(IV) was varied in the range of $(0.5-$ 5.0) $\times 10^{-4} \mathrm{~mol} \mathrm{dm}^{-3}$ keeping other variables constant. It has been observed that the increase in the oxidant concentration did not alter the rate constant value (Table 1). Also, the plots of $\ln$ (absorbance) versus time were found to be good straight lines. These results indicate that the order of reaction with respect to the oxidant concentration is confirmed to be one.

The observed rate constant was determined at different initial $[\mathrm{Py}-\mathrm{F}]$ while other variables were kept constant. Increasing $[\mathrm{Py}-\mathrm{F}]$ increased the reaction rate as listed in Table 1. A plot of the $k_{\mathrm{obs}}$ versus [Py-F] at constant $\mathrm{pH}$ is linear with a positive intercept as shown in Figure 2 confirming fractional-first order dependence with respect to $[\mathrm{Py}-\mathrm{F}]$.

Kinetic runs were carried out by varying the hydrogen ion concentration $\left(0.1-0.9 \mathrm{~mol} \mathrm{dm}^{-3}\right)$ and keeping the concentrations of all other reactants constant. It was observed that the rate of the reaction decreased with increasing $\left[\mathrm{H}^{+}\right]$ (Table 1). A plot of $k_{\mathrm{obs}}$ versus $\left[\mathrm{H}^{+}\right]$was linear with a negative slope (Figure 3) confirming negative fractional-first order dependence with respect to $\left[\mathrm{H}^{+}\right]$. 


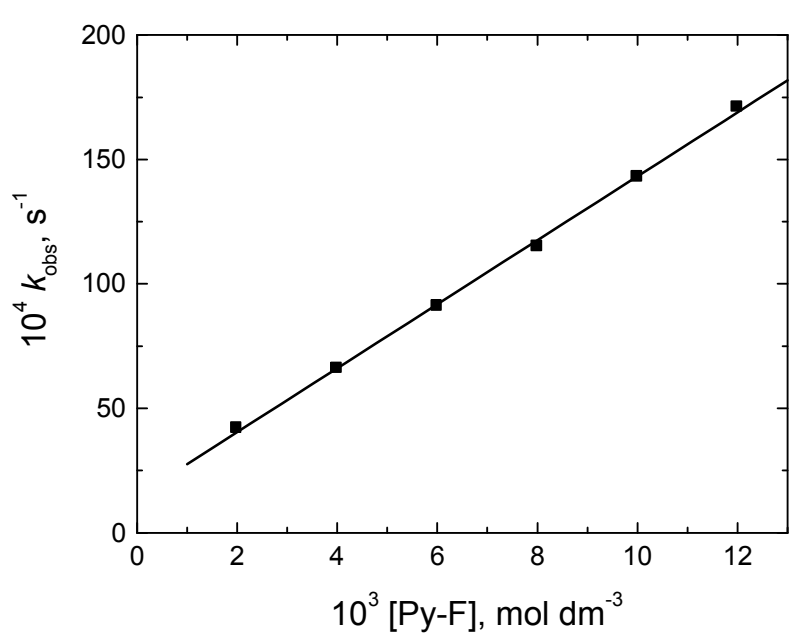

Figure 2. Plot of $k_{\text {obs }}$ versus $[P y-F]$ in the oxidation of Py-F by Ce(IV) in perchloric acid solution. $[\mathrm{Ce}(\mathrm{IV})]=2.0 \times 10^{-4},\left[\mathrm{H}^{+}\right]=0.3$ and $I=1.0 \mathrm{~mol}$ $d m^{-3}$ at $20^{\circ} \mathrm{C}$.

Table 1. Effect of [Ce(IV)], $[\mathrm{Py}-\mathrm{F}]$ and $\left[\mathrm{H}^{+}\right]$on $\mathrm{k}_{\text {obs }}$ in the oxidation of $\mathrm{Py}-\mathrm{F}$ by $\mathrm{Ce}(\mathrm{IV})$ in perchloric acid solutions at $20^{\circ} \mathrm{C}$.

\begin{tabular}{|c|c|c|c|c|}
\hline $\begin{array}{l}10^{4}[\mathrm{Ce}(\mathrm{IV})], \\
\mathrm{mol} \mathrm{dm}^{-3}\end{array}$ & $\begin{array}{l}10^{3}[\mathrm{Py}-\mathrm{F}], \\
\mathrm{mol} \mathrm{dm}^{-3}\end{array}$ & 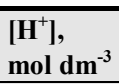 & $I, \mathrm{~mol} \mathrm{dm}{ }^{-3}$ & $10^{4} k_{\mathrm{obs}}, \mathrm{s}^{-1}$ \\
\hline 0.5 & 8.0 & 0.3 & 1.0 & 117 \\
\hline 1.0 & 8.0 & 0.3 & 1.0 & 111 \\
\hline 2.0 & 8.0 & 0.3 & 1.0 & 115 \\
\hline 3.0 & 8.0 & 0.3 & 1.0 & 116 \\
\hline 4.0 & 8.0 & 0.3 & 1.0 & 113 \\
\hline 5.0 & 8.0 & 0.3 & 1.0 & 117 \\
\hline 2.0 & 2.0 & 0.3 & 1.0 & 42 \\
\hline 2.0 & 4.0 & 0.3 & 1.0 & 67 \\
\hline 2.0 & 6.0 & 0.3 & 1.0 & 91 \\
\hline 2.0 & 8.0 & 0.3 & 1.0 & 115 \\
\hline 2.0 & 10.0 & 0.3 & 1.0 & 144 \\
\hline 2.0 & 12.0 & 0.3 & 1.0 & 171 \\
\hline 2.0 & 8.0 & 0.1 & 1.0 & 146 \\
\hline 2.0 & 8.0 & 0.2 & 1.0 & 129 \\
\hline 2.0 & 8.0 & 0.3 & 1.0 & 115 \\
\hline 2.0 & 8.0 & 0.5 & 1.0 & 93 \\
\hline 2.0 & 8.0 & 0.7 & 1.0 & 75 \\
\hline 2.0 & 8.0 & 0.9 & 1.0 & 59 \\
\hline 2.0 & 8.0 & 0.3 & 1.0 & 115 \\
\hline 2.0 & 8.0 & 0.3 & 1.2 & 112 \\
\hline 2.0 & 8.0 & 0.3 & 1.4 & 116 \\
\hline 2.0 & 8.0 & 0.3 & 1.6 & 121 \\
\hline 2.0 & 8.0 & 0.3 & 1.8 & 118 \\
\hline 2.0 & 8.0 & 0.3 & 2.0 & 113 \\
\hline
\end{tabular}

Experimental error $\pm 4 \%$.

\subsection{Effect of Ionic Strength and Dielectric Constant of the Reaction Medium}

The effect of ionic strength on the rate of the reaction was studied by varying the ionic strength in the range $1.0-2.0$ mol dm${ }^{-3}$ using sodium perchlorate as an inert electrolyte with keeping the concentrations of all other reactants constant. The results indicated that variation of ionic strength was found to have negligible effect on the reaction rate.

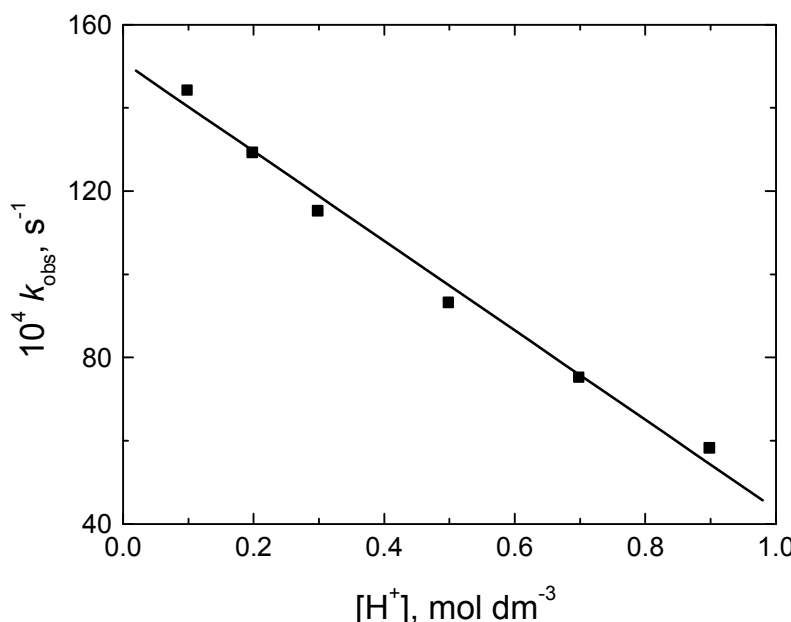

Figure 3. Plot of $k_{\text {obs }}$ versus $\left[\mathrm{H}^{+}\right]$in the oxidation of $\mathrm{Py}-\mathrm{F}$ by $\mathrm{Ce}(\mathrm{IV})$ in perchloric acid solution. $[P y-F]=8.0 \times 10^{-3},[C e(I V)]=2.0 \times 10^{-4}$ and $I=$ $1.0 \mathrm{~mol} \mathrm{dm}^{-3}$ at $20^{\circ} \mathrm{C}$.

The dielectric constant $(D)$ effect was studied by varying the acetic acid - water content in the reaction mixture with all other conditions being kept constant. The dielectric constant was computed from the values of dielectric constants of pure liquids by considering their $D$ in pure form using equation: $D$ $=D_{1} V_{1}+D_{2} V_{2}$, where $V_{1}$ and $V_{2}$ are volume fractions and $D_{1}$ and $D_{2}$ are dielectric constants of water and acetic acid as 78.5 and 6.15 , respectively. The rate constants increased negligibly with decreasing the dielectric constants of the reaction medium.

\subsection{Effect of Initially Added Product}

The effect of added cerium(III) product was studied in the concentration range $0.4 \times 10^{-4}$ to $9.0 \times 10^{-4} \mathrm{~mol} \mathrm{dm}^{-3}$ at constant concentrations of the oxidant, reductant and acid. It was found that $\mathrm{Ce}$ (III) did not have any significant effect on the rate of reaction.

\subsection{Effect of Temperature}

The rate of reaction was carried out at five temperatures namely, 293, 298, 303, 308 and $313 \mathrm{~K}$, at constant concentrations of the reactants and other conditions being constant. The results indicate that the observed first order rate constant was increased with raising temperature. The activation parameters of the second order rate constant $\left(k_{2}\right)$ are calculated using Arrhenius, Figure 4a, and Eyring, Figure 4b, plots and are listed in Table 2. 


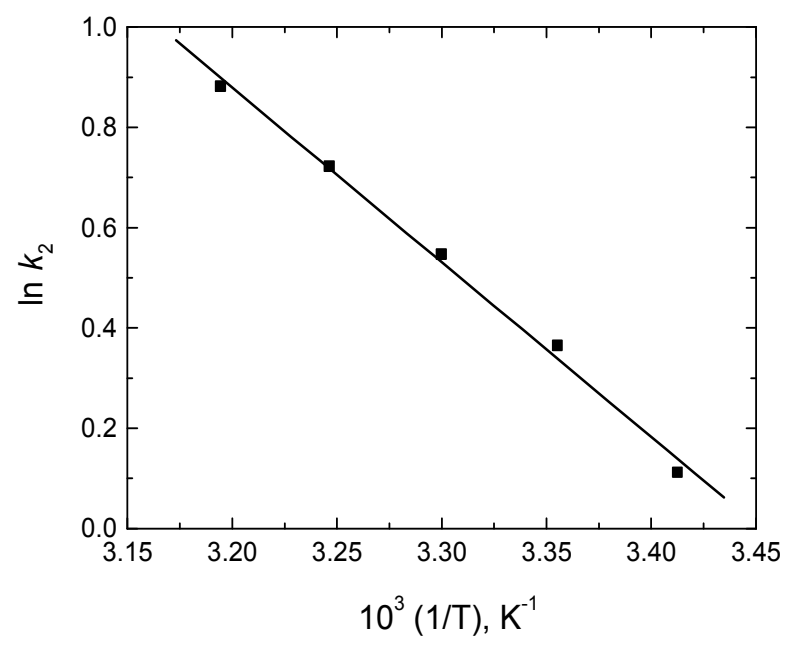

(a)

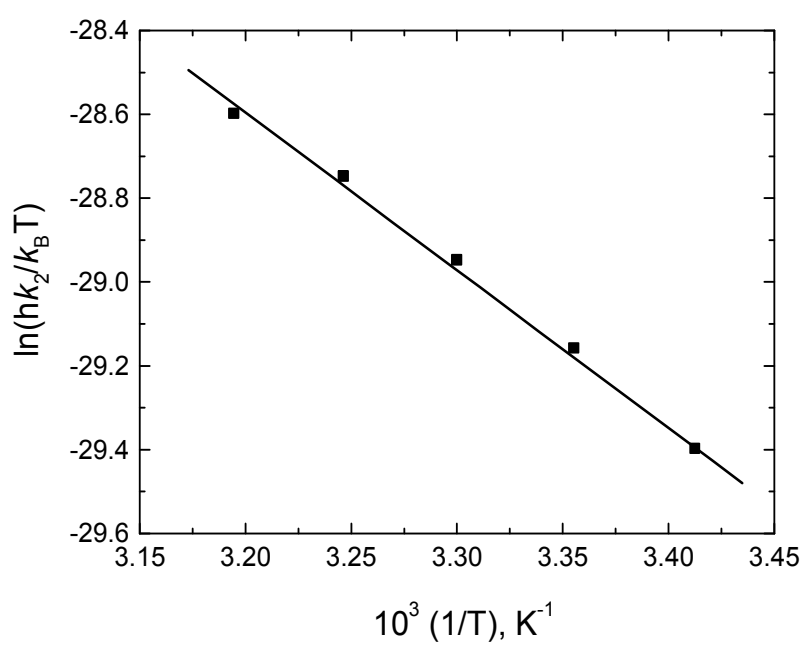

(b)

Figure 4. a) Arrhenius and, b) Eyring plots in the oxidation of Py-F by $\mathrm{Ce}(\mathrm{IV})$ in perchloric acid solutions. $[\mathrm{Py}-\mathrm{F}]=8.0 \times 10^{-3},[\mathrm{Ce}(\mathrm{IV})]=2.0 \times 10^{-}$ ${ }^{4},\left[\mathrm{H}^{+}\right]=0.3$ and $I=1.0 \mathrm{~mol} \mathrm{dm}{ }^{-3}$.

Table 2. Activation parameters of the second order rate constant $k_{2}$ in the oxidation of Py-F by $\mathrm{Ce}(\mathrm{IV})$ in perchloric acid solutions. $[\mathrm{Py}-\mathrm{F}]=8.0 \times 10^{-3}$, $[\mathrm{Ce}(I V)]=2.0 \times 10^{-4},\left[\mathrm{H}^{+}\right]=0.3$ and $I=1.0 \mathrm{~mol} \mathrm{dm}{ }^{-3}$.

\begin{tabular}{|c|c|c|c|}
\hline$\Delta S^{\ddagger}, \mathrm{J} \mathrm{mol}^{-1} \mathrm{~K}^{-1}$ & $\Delta H^{\ddagger}, \mathrm{kJ} \mathrm{mol}^{-1}$ & $\Delta G_{298}^{\ddagger}, \mathrm{kJ} \mathrm{mol}^{-1}$ & $E_{\mathrm{a}}^{\neq}, \mathrm{kJ} \mathrm{mol}^{-1}$ \\
\hline-139.68 & 30.76 & 72.83 & 29.59 \\
\hline
\end{tabular}

Experimental error $\pm 4 \%$.

\subsection{Polymerization Test}

The intervention of free radicals during the reaction was examined by polymerization test. The reaction mixture to which a known quantity of acrylonitrile scavenger has been added initially was kept in an inert atmosphere for about $6 \mathrm{~h}$. Upon diluting the reaction mixture with methanol, a white precipitate has been formed, suggesting generation of a free radical in the reaction. When the experiment was repeated in the absence of Py-F under similar conditions, the test was negative. This indicates that the reaction was routed through a free radical path.

\section{Discussion}

It was reported [25-27] that the active species of cerium(IV) in perchloric acid solutions was found to be either free monomeric species $\mathrm{Ce}^{4+}$, its hydrolyzed forms, $\mathrm{Ce}(\mathrm{OH})^{3+}$ and $\mathrm{Ce}(\mathrm{OH})_{2}{ }^{2+}$ or partially in the form of dimeric species $(\mathrm{Ce}-\mathrm{O}-\mathrm{Ce})^{6+}$ and $(\mathrm{HOCe}-\mathrm{O}-\mathrm{CeOH})^{4+}$. However, Offiner and Skoog [28] showed from the spectrophotometric studies that the hydrated form, $\mathrm{Ce}^{4+}$, is the predominant species at $\left[\mathrm{H}^{+}\right] \geq 1.0 \mathrm{~mol} \mathrm{dm}{ }^{-3}$ up to the concentration of 1.5 x $10^{-3} \mathrm{~mol} \mathrm{dm}^{-3}$ of cerium(IV), whereas the hydrolyzed forms and dimers are the more predominant at $\left[\mathrm{H}^{+}\right]<0.8 \mathrm{~mol}$ $\mathrm{dm}^{-3}$. Therefore, under our experimental conditions of low $\left[\mathrm{H}^{+}\right]$and deceasing reaction rate with increasing $\left[\mathrm{H}^{+}\right]$, $\mathrm{Ce}(\mathrm{OH})^{3+}$ may be regarded as the kinetically active form of cerium(IV) according to the following equilibria,

$$
\mathrm{Ce}^{4+}+\mathrm{H}_{2} \mathrm{O} \stackrel{K_{\mathrm{OH}}}{=} \mathrm{Ce}(\mathrm{OH})^{3+}+\mathrm{H}^{+}
$$

The present reaction between Py-F and Ce(IV) in aqueous perchloric acid solutions has a stoichiometry of $1: 2$, i.e., one mole of Py-F requires two moles of $\mathrm{Ce}(\mathrm{IV})$. The reaction exhibited first order dependence with respect to [Ce(IV)], less than unit order with respect to $[\mathrm{Py}-\mathrm{F}]$ and negative fractional order in $\left[\mathrm{H}^{+}\right]$. The rate is not considerably affected by $\mathrm{Ce}$ (III) suggesting that the probability of any fast equilibrium with the product preceding the rate-determining step was ruled out. The rate-determining step should be irreversible as is generally the case for one electron oxidants [30] and the oxidation takes place through generation of free radical as obtained experimentally. The rate of reaction was not considerably affected by variation of either ionic strength or dielectric constant of the reactions medium suggesting that the reaction occur between a neutral molecule and a charged ion $[31,32]$.

The less than unit order with respect to [Py-F] may be as a result of complex formation between the kinetically active $\mathrm{Ce}(\mathrm{IV})$ species and Py-F $\left(\mathrm{C}_{1}\right)$ prior to the rate-determining step. Complex formation was proved kinetically by the nonzero intercepts of the plot of $1 / k_{\text {obs }}$ versus $1 /[\mathrm{Py}-\mathrm{F}]$ (Figure 5) in favor of possible formation of an intermediate complex between the oxidant and substrate, similar to the well-known Michaelis-Menten [33] mechanism for enzyme-substrate reactions. The formed complex was slowly decomposed in the rate-determining step to give rise to the initial oxidation products as the substrate radical $\left(\mathrm{Py}-\mathrm{F}^{*}\right)$ and $\mathrm{Ce}(\mathrm{III})$. The substrate radical reacts with another $\mathrm{Ce}(\mathrm{IV})$ species in a subsequent fast step to yield an intermediate product, $\mathrm{N}, \mathrm{N}$ dimethyl- $N$ '-(pyridin-2-yl) urea. In a further fast step, the intermediate product is hydrolyzed to give the final oxidation products as given in the following mechanistic scheme,

$$
\mathrm{Ce}^{4+}+\mathrm{H}_{2} \mathrm{O} \stackrel{\mathrm{K}_{\mathrm{OH}}}{=} \mathrm{Ce}(\mathrm{OH})^{3+}+\mathrm{H}^{+}
$$

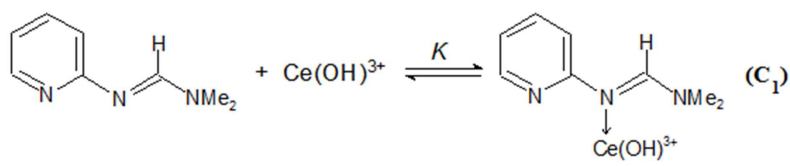




$$
\text { fast }
$$

Since the mechanistic scheme is in accordance with the generally well-accepted principle of non-complementary oxidations taking place in a sequence of one-electron steps, the reaction between the substrate and oxidant would afford radical intermediate as was obtained experimentally.

The suggested mechanism leads to the following rate law expression (see Appendix A),

$$
\text { Rate }=\frac{k_{1} K_{\mathrm{OH}} K[\mathrm{Ce}(\mathrm{IV})][\mathrm{Py}-\mathrm{F}]}{\left[\mathrm{H}^{+}\right]+K_{\mathrm{OH}}+K_{\mathrm{OH}} K[\mathrm{Py}-\mathrm{F}]}
$$

Under pseudo-first order condition, the rate-law can be expressed by Eq. (8),

$$
\text { Rate }=\frac{-d[\mathrm{Ce}(\mathrm{IV})]}{d t}=k_{\mathrm{obs}}[\mathrm{Ce}(\mathrm{IV})]
$$

Comparing Eqs. (7) and (8), the following relationship is obtained,

$$
k_{\mathrm{obs}}=\frac{k_{1} K_{\mathrm{OH}} K[\mathrm{Py}-\mathrm{F}]}{\left[\mathrm{H}^{+}\right]+K_{\mathrm{OH}}+K_{\mathrm{OH}} K[\mathrm{Py}-\mathrm{F}]}
$$

The rate law (7) is consistent with all the observed orders with respect to different species, which can be verified by rearranging to the following equations,

$$
\begin{gathered}
\frac{1}{k_{\mathrm{obs}}}=\left(\frac{\left[\mathrm{H}^{+}\right]+K_{\mathrm{OH}}}{k_{1} K_{\mathrm{OH}} K}\right) \frac{1}{[\mathrm{Py}-\mathrm{F}]}+\frac{1}{k_{1}} \\
\frac{1}{k_{\mathrm{obs}}}=\left(\frac{1}{k_{1} K_{\mathrm{OH}} K[\mathrm{Py}-\mathrm{F}]}\right)\left[\mathrm{H}^{+}\right]+\frac{1}{k_{1} K[\mathrm{Py}-\mathrm{F}]}+\frac{1}{k_{1}}
\end{gathered}
$$

According to Eqs. (10) and (11), plots of $1 / k_{\mathrm{obs}}$ versus $1 /[\mathrm{Py}-\mathrm{F}]$ at constant $\left[\mathrm{H}^{+}\right]$, and $1 / k_{\text {obs }}$ versus $\left[\mathrm{H}^{+}\right]$at constant [Py-F] should be linear with positive intercepts and are found to be so as shown in Figures 5 and 6, respectively. From the slopes and intercepts of these plots, the values of $k_{1}, K_{\mathrm{OH}}$, and $K$ could be evaluated and were found to be $31.25 \times 10^{-3} \mathrm{~s}^{-1}$, $0.17 \mathrm{~mol} \mathrm{dm}^{-3}$, and $202.17 \mathrm{dm}^{3} \mathrm{~mol}^{-1}$, respectively at $20{ }^{\circ} \mathrm{C}$.

The obtained activation parameters listed in Table 2 can be discussed as follows. The negative value of $\Delta S^{\#}$ suggests interaction of reacting ions to form an intermediate complex of inner-sphere nature $[34,35]$. This value is within the range of radical reactions and has been ascribed to the nature of the electron pairing and unpairing process and to the loss of degree of freedom formerly available to the reactants upon formation of a rigid transition state [36, 37]. The values of $\Delta H^{\ddagger}$ and $\Delta S^{\ddagger}$ are both favorable for electron transfer processes. On the other hand, the positive values of both $\Delta H^{\ddagger}$ and $\Delta G^{f}$ indicate endothermic formation of the complex and its non-spontaneity, respectively.

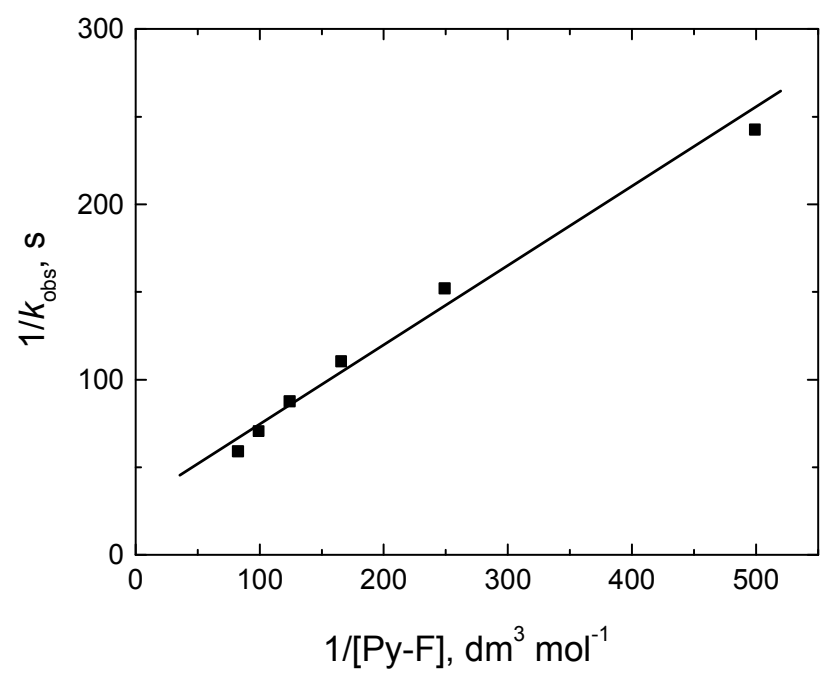

Figure 5. Plot of $1 / k_{\text {obs }}$ versus $1 /[\mathrm{Py}-\mathrm{F}]$ in the oxidation of $\mathrm{Py}-\mathrm{F}$ by $\mathrm{Ce}(\mathrm{IV})$ in perchloric acid solution. $[\mathrm{Ce}(\mathrm{IV})]=2.0 \times 10^{-4},\left[\mathrm{H}^{+}\right]=0.3$ and $I=1.0 \mathrm{~mol}$ $d m^{-3}$ at $20^{\circ} \mathrm{C}$.

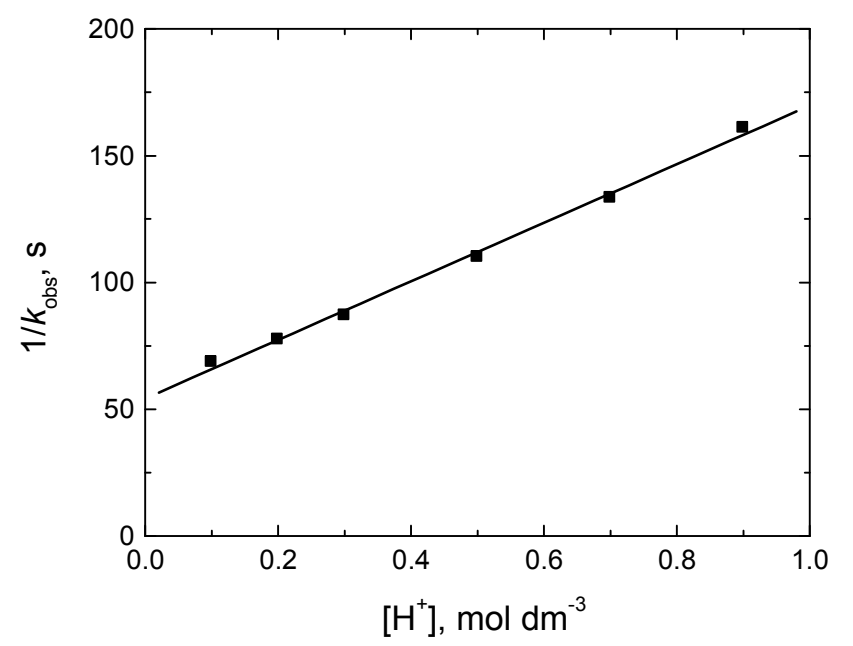

Figure 6. Plot of $1 / k_{\text {obs }}$ versus $\left[H^{+}\right]$in the oxidation of $P y-F$ by $\mathrm{Ce}(\mathrm{IV})$ in perchloric acid solution. $[\mathrm{Py}-\mathrm{F}]=8.0 \times 10^{-3},[\mathrm{Ce}(\mathrm{IV})]=2.0 \times 10^{-4}$ and $\mathrm{I}=$ $1.0 \mathrm{~mol} \mathrm{dm}^{-3}$ at $20^{\circ} \mathrm{C}$.

\section{Appendix A. Derivation of the Rate Law Expression}

According to the suggested mechanism and regarding to reaction (3),

Rate $=\frac{-d[\mathrm{Ce}(\mathrm{IV})]}{d t}=k_{1}\left[\mathrm{C}_{1}\right]$ 
Regarding to reactions (1) and (2),

$K_{\mathrm{OH}}=\frac{\left[\mathrm{Ce}(\mathrm{OH})^{3+}\right]\left[\mathrm{H}^{+}\right]}{\left[\mathrm{Ce}^{4+}\right]}, \quad\left[\mathrm{Ce}(\mathrm{OH})^{3+}\right]=\frac{K_{\mathrm{OH}}\left[\mathrm{Ce}^{4+}\right]}{\left[\mathrm{H}^{+}\right]}$

and

$K=\frac{\left[\mathrm{C}_{1}\right]}{\left[\mathrm{Ce}(\mathrm{OH})^{3+}\right][\mathrm{Py}-\mathrm{F}]}$,

$\left[\mathrm{C}_{1}\right]=K\left[\mathrm{Ce}(\mathrm{OH})^{3+}\right][\mathrm{Py}-\mathrm{F}]=\frac{K_{\mathrm{OH}} K\left[\mathrm{Ce}^{4+}\right][\mathrm{Py}-\mathrm{F}]}{\left[\mathrm{H}^{+}\right]}$

Substituting Eq. (A3) into Eq. (A1) leads to,

Rate $=\frac{k_{1} K_{\mathrm{OH}} K\left[\mathrm{Ce}^{4+}\right][\mathrm{Py}-\mathrm{F}]}{\left[\mathrm{H}^{+}\right]}$

The total concentration of $\mathrm{Py}-\mathrm{F}$ is given by:

$[\mathrm{Py}-\mathrm{F}]_{\mathrm{T}}=[\mathrm{Py}-\mathrm{F}]_{\mathrm{F}}+\left[\mathrm{C}_{1}\right]$

where ' $\mathrm{T}$ ' and ' $\mathrm{F}$ ' stand for total and free concentrations.

Substituting Eq. (A3) into Eq. (A5) and rearrangement gives,

$[\mathrm{Py}-\mathrm{F}]_{\mathrm{T}}=[\mathrm{Py}-\mathrm{F}]_{\mathrm{F}}+\frac{K_{\mathrm{OH}} K\left[\mathrm{Ce}^{4+}\right][\mathrm{Py}-\mathrm{F}]}{\left[\mathrm{H}^{+}\right]}$

$[\mathrm{Py}-\mathrm{F}]_{\mathrm{T}}=[\mathrm{Py}-\mathrm{F}]_{\mathrm{F}}\left(1+\frac{K_{\mathrm{OH}} K\left[\mathrm{Ce}^{4+}\right]}{\left[\mathrm{H}^{+}\right]}\right)$

Therefore,

$[\mathrm{Py}-\mathrm{F}]_{\mathrm{F}}=\frac{[\mathrm{Py}-\mathrm{F}]}{1+\frac{K_{\mathrm{OH}} K\left[\mathrm{Ce}^{4+}\right]}{\left[\mathrm{H}^{+}\right]}}$

In view of low $\left[\mathrm{Ce}^{4+}\right]$, the second denominator term $K_{\mathrm{OH}} K\left[\mathrm{Ce}^{4+}\right] /\left[\mathrm{H}^{+}\right]$in the above equation is neglected.

Therefore,

$[\mathrm{Py}-\mathrm{F}]_{\mathrm{F}}=[\mathrm{Py}-\mathrm{F}]_{\mathrm{T}}$

Also,

$[\mathrm{Ce}(\mathrm{IV})]_{\mathrm{T}}=\left[\mathrm{Ce}^{4+}\right]_{\mathrm{F}}+\left[\mathrm{Ce}(\mathrm{OH})^{3+}\right]+\left[\mathrm{C}_{1}\right]$

Substituting Eqs. (A2) and (A3) into Eq. (A10),

$[\mathrm{Ce}(\mathrm{IV})]_{\mathrm{T}}=\left[\mathrm{Ce}^{4+}\right]_{\mathrm{F}}+\frac{K_{\mathrm{OH}}\left[\mathrm{Ce}^{4+}\right]}{\left[\mathrm{H}^{+}\right]}+\frac{K_{\mathrm{OH}} K\left[\mathrm{Ce}^{4+}\right][\mathrm{Py}-\mathrm{F}]}{\left[\mathrm{H}^{+}\right]}$

$[\mathrm{Ce}(\mathrm{IV})]_{\mathrm{T}}=\left[\mathrm{Ce}^{4+}\right]_{\mathrm{F}}\left(1+\frac{K_{\mathrm{OH}}}{\left[\mathrm{H}^{+}\right]}+\frac{K_{\mathrm{OH}} K[\mathrm{Py}-\mathrm{F}]}{\left[\mathrm{H}^{+}\right]}\right)$

$\left[\mathrm{Ce}^{4+}\right]_{\mathrm{F}}=\frac{[\mathrm{Ce}(\mathrm{IV})]_{\mathrm{T}}}{1+\frac{K_{\mathrm{OH}}}{\left[\mathrm{H}^{+}\right]}+\frac{K_{\mathrm{OH}} K[\mathrm{Py}-\mathrm{F}]}{\left[\mathrm{H}^{+}\right]}}$

Substituting Eqs. (A9) and (A13) into Eq. (A4) (and omitting ' $\mathrm{T}$ ' and ' $\mathrm{F}$ ' subscripts) leads to,

$$
\text { Rate }=\frac{k_{1} K_{\mathrm{OH}} K[\mathrm{Ce}(\mathrm{IV})[\mathrm{Py}-\mathrm{F}]}{1+\frac{K_{\mathrm{OH}}}{\left[\mathrm{H}^{+}\right]}+\frac{K_{\mathrm{OH}} K[\mathrm{Py}-\mathrm{F}]}{\left[\mathrm{H}^{+}\right]}}=\frac{k_{1} K_{\mathrm{OH}} K[\mathrm{Ce}(\mathrm{IV})[\mathrm{Py}-\mathrm{F}]}{\left[\mathrm{H}^{+}\right]+K_{\mathrm{OH}}+K_{\mathrm{OH}} K[\mathrm{Py}-\mathrm{F}]}
$$

Under pseudo-first order condition, the rate-law can be expressed by Eq. (A15),

$$
\text { Rate }=\frac{-d[\mathrm{Ce}(\mathrm{IV})]}{d t}=k_{\mathrm{obs}}[\mathrm{Ce}(\mathrm{IV})]
$$

Comparing Eqs. (A14) and (A15), the following relationship is obtained,

$$
k_{\mathrm{obs}}=\frac{k_{1} K_{\mathrm{OH}} K[\mathrm{Py}-\mathrm{F}]}{\left[\mathrm{H}^{+}\right]+K_{\mathrm{OH}}+K_{\mathrm{OH}} K[\mathrm{Py}-\mathrm{F}]}
$$

and with rearrangement, the following equations are obtained,

$\frac{1}{k_{\mathrm{obs}}}=\left(\frac{\left[\mathrm{H}^{+}\right]+K_{\mathrm{OH}}}{k_{1} K_{\mathrm{OH}} K_{1}}\right) \frac{1}{[\mathrm{Py}-\mathrm{F}]}+\frac{1}{k_{1}}$

$\frac{1}{k_{\mathrm{obs}}}=\left(\frac{1}{k_{1} K_{\mathrm{OH}} K_{1}[\mathrm{Py}-\mathrm{F}]}\right)\left[\mathrm{H}^{+}\right]+\frac{1}{k_{1} K_{1}[\mathrm{Py}-\mathrm{F}]}+\frac{1}{k_{1}}$

\section{References}

[1] Beeman RW, Matsumura F (1973) Chlordimeform: a pesticide acting upon amine regulatory mechanisms. Nature. 242: 273274.

[2] Aziz AA, Knowles CO (1973) Inhibition of monoamine oxidase by the pesticides chlordimeform and related compounds. Nature 242: 417-418.

[3] Leung VSK, Chan TYK, Yeung VTF (1999) Ami-traz poisoning in humans, Clinical Toxicol. 37: 513-514.

[4] Nakayama A, Sukekawa M, Eguchi Y (1997) Stereochemistry and active conformation of a novel insecticide Acetamiprid. Pesticide Sci. 51: 157-164.

[5] Fawzy A (2016) Oxidation of alginate and pectate biopolymers by cerium(IV) in perchloric and sulfuric acid solutions: A comparative kinetic and mechanistic study, Carbohydr. Polym. 138: 356-364.

[6] Mathur S, Yadav MB, Devra V (2013) Kinetics and mechanism of uncatalyzed and $\operatorname{Ag}(\mathrm{I})$ catalyzed oxidation of hydroxylysine by cerium (IV) in acid medium. J. Phys. Chem. Biophys. 3: 5-12.

[7] Mathur S, Yadav MB, Devra V (2015) Kinetics and mechanism of uncatalyzed and $\operatorname{Ag}(\mathrm{I})$ catalyzed oxidation of serine by cerium(IV) in acid medium. Int. J. Res. Phys. Chem. 5: $1-6$.

[8] Thabaj KA, Chimatadar SA, Nandibewoor ST (2006) Mechanistic study of oxidation of palladium(II) by cerium(IV) in aqueous acid. Transition Met. Chem. 31: 186-193.

[9] Bolattin M, Meti M, Nandibewoor ST, Chimatadar SA (2015) Catalytic activity of ruthenium(III) and thermodynamic study of oxidative degradation of chloramphenicol by cerium(IV) in sulfuric acid medium. J. Solution Chem.44: 152-169. 
[10] Hosahalli RV, Savanur AP, Nandibewoor ST, Chimatadar SA (2010) Ruthenium(III)-mediated oxidation of D-mannitol by cerium(IV) in aqueous sulfuric acid medium: A kinetic and mechanistic approach. Int. J. Chem. Kinet. 42: 440-452.

[11] Das A. K, Islam M, Bayen R (2008) Studies on kinetics and mechanism of oxidation of D-sorbitol and D-mannitol by cerium(IV) in aqueous micellar sulfuric acid media. Int. J. Chem. Kinet. 40: 445-453.

[12] Adari KK, Nowduri A, Parvataneni V (2008) Kinetics and mechanism of oxidation of L-cystine by cerium(IV) in sulphuric acid medium. Acta Chim. Slov. 55: 425-429.

[13] Sumathi T, Shanmugasundaram P, Chandramohan G (2011) A kinetic and mechanistic study on the silver(I) catalyzed oxidation of L-Serine by cerium(IV) in sulfuric acid medium. J. Saudi Chem. Soc. in press.

[14] Hassan RM, Alaraifi A, Fawzy A, Zaafarany IA, Khairou KS, Ikeda Y, Takagi HD (2010) Acid-catalyzed oxidation of some sulfated polysaccharides. Kinetics and mechanism of oxidation of kappa-carrageenan by cerium(IV) in aqueous perchlorate solutions. J. Mol. Cat. A, 332: 138-144.

[15] Naik DV, Byadagi KS, Nandibewoor ST, Chimatadar SA (2013) Kinetics and mechanistic study of manganese(II)catalyzed cerium(IV) oxidation of thiamine hydrochloride in aqueous perchloric acid medium by stopped flow technique, Monatshefte für Chemie 144: 1307-1317.

[16] Byadagi KS, Naik DV, Savanur AP, Nandibewoor ST, Chimatadar SA (2010) Ruthenium(III) mediated oxidation of thiamine hydrochloride by cerium(IV) in perchloric acid medium: a kinetic and mechanistic approach. React. Kinet. Mech. Catal. 99: 53-61.

[17] Jattinagoudar LN, Byadagi KS, Nandibewoor ST, Chimatadar SA (2015) Kinetics and mechanism of cerium(IV) oxidation of fosfomycin disodium salt: an antibiotic drug in acid perchlorate solutions. Org. Nano Met. Chem. 45: 1138-1144.

[18] Khan F, Kushwaha U, Singh AK (2012) A mechanistic study based on kinetics of the oxidation of diethyl ketone by $\operatorname{Ir}(\mathrm{III})$ chloride in aqueous perchloric acid medium when cerium(IV) perchlorate is used as a catalyst. J. Chem. Pharm. Res. 4: 3715-3726.

[19] Yadav MB, Derva V, Rani A (2009) Kinetics and mechanism of uncatalyzed and silver(I) catalyzed oxidation of lysine by cerium(IV) in acid perchlorate medium. J. Indian Chem. Soc. 86: 600-604.

[20] Datt N, Nagori RR, Mehrotra RN (1986) Kinetics and mechanisms of oxidations by metal ions. Part VI. Oxidation of $\alpha$-hydroxy acids by cerium(IV) in aqueous nitric acid. Can. J. Chem. 64: 19-23.

[21] Fawzy A, Shaaban MR (2014) Kinetic and mechanistic investigations on the oxidation of N'-heteroaryl unsymmetrical formamidines by permanganate in aqueous alkaline medium. Transition Met. Chem. 39: 379-386.
[22] Hardwick TJ, Robertson E (1951) Ionic species in ceric perchlorate solutions. Can. J. Chem. 29: 818-828.

[23] Vogel AI (1973) Text book of practical organic chemistry including quantitative organic analysis, 3rd edn, $332 \mathrm{pp}$. ELBS, Longman.

[24] Feigl F (1975) Spot tests in organic analysis, 195 pp. Elsevier, New York.

[25] Sherill MS, King CB, Spooner RC (1943) The oxidation potential of cerous-ceric perchlorates. J. Am. Chem. Soc. 65: 170-179.

[26] Heidt LJ, Smith ME (1948) Quantum yields of the photochemical reduction of ceric ions by water and evidence for the dimerization of ceric ions. J. Am. Chem. Soc. 70: 2476-2481.

[27] King EL, Pandow ML (1952) The spectra of cerium(IV) in perchloric acid. Evidence for polymeric species. J. Am. Chem. Soc. 74: 1966-1969.

[28] Offner HG, Skoog DA (1966) Hydrolysis constant of quadrivalent cerium from spectrometric measurements. Anal. Chem. 38: 1520-1521.

[29] Chimatadar SA, Madawale SV, Nandibewoor ST (2007) Mechanistic study of iodide catalysed oxidation of L-glutamic acid by cerium(IV) in aqueous sulphuric acid medium. Transition Met. Chem. 32: 634-641.

[30] Leal JM, Domingo PL, Garcla B, Ibeas S (1993) Alkali metal ion catalysis of the oxidation of L-ascorbic acid by hexacyanoferrate(III) in strongly acidic media. J. Chem. Soc. Faraday Trans. 89: 3571-3577.

[31] Frost AA, Person RG (1973) Kinetics and mechanism, 147 pp. Wiley Eastern, New Delhi.

[32] Amis ES (1966) Solvent effect on reaction rates and mechanism, pp. 28, Academic Press, New York.

[33] Michaelis L, Menten ML (1913) The kinetics of invertase action. Biochem. Z. 49: 333-369.

[34] Fawzy A (2015) Kinetics and mechanistic approach to the oxidative behavior of biological anticancer platinum(IV) complex towards L-asparagine in acid medium and the effect of copper(II) catalyst. Int. J. Chem. Kinet. 47: 1-12.

[35] Freeman F, Fuselier CO, Armstead CR, Dalton CE, Davidson PA, Karchesfski EM, Krochman DE, Johnson MN, Jones NK. (1981) Permanganate ion oxidations. 13. Soluble manganese(IV) species in the oxidation of 2, $4(1 \mathrm{H}, 3 \mathrm{H})$ pyrimidinediones (uracils). J. Am. Chem. Soc. 103: 11541159.

[36] Hicks KW, Toppen DL, Linck RG (1972) Inner-sphere electron-transfer reactions of vanadium(II) with azidoamine complexes of cobalt(III). Inorg. Chem. 11: 310-315.

[37] Walling C (1957) Free radical in solutions, (pp. 38). New York: Academic Press. 